\title{
IMPACT OF BONE MARROW STEM CELLS APPLICATION ON THE METHOTREXATE INDUCED SUBMANDIBULAR SALIVARY GLAND DEGENERATIVE CHANGES IN ALBINO RATS (HISTOLOGICAL AND IMMUNO-HISTOCHEMICAL STUDY)
}

\author{
Heba Fathy El Emam**, Nesreen Nabil Abd El Salam ${ }^{* *}$ and Shaimaa Eliwa Ghazy ${ }^{* * *}$
}

\begin{abstract}
Introduction: cytotoxic drugs produce a structural changes in salivary glands that results in disturbances in their function. Patients treated with these cytotoxic drugs complain from xerostomia that results in difficulties in swallowing, speech, taste sensation, oropharyngeal pain and oral infections. Aim: This is study was conducted to evaluate the effect of local injection of bone marrow stem cells on submandibular glands of rats receiving Methotrexate as chemotherapeutic drug histologically and immunohistochemically.
\end{abstract}

Materials and Methods: Thirty male adult albino rats (150-200 gm). They were randomly divided into three groups $(n=10)$. Group I: rats were received single intraperitoneal injection of Phosphate buffered saline PBS $1 \mathrm{ml}$ at the day one of the experiment. Group II: rats received single intraperitoneal injection of $40 \mathrm{mg} / \mathrm{kg}$ Methotrexate (MTX) dissolved in $1 \mathrm{ml}$ saline at day one of the experiment. Groups III: rats were handled as those in group II; however, rats were subjected to intra glandular injection of bone marrow stem cells (BMMSCs) suspended in $0.1 \mathrm{ml}$ PBS 7 days after the start of the experiment at both sides of submandibular salivary gland (SMG). Animals of all groups were euthanized at three weeks after the start of experiment and two pairs of (SMG) were dissected out, processed and the prepared sections were examined histologically by H\&E, immunohistochemical stain for Bcl-2 and morphomtrical analysis. Data obtained from immunohistochemical analysis were statistically described in terms of mean \pm standard deviation $( \pm S D)$.

Results: Histological examination of Group I revealed the normal histological structure of the gland and mild positive immunoreaction of Bcl-2. Group II has glandular disorganization. The nuclei of the acinar cells revealed different sizes and shape (polymorphism) and negative immunoreactivity for Bcl-2. Group (III) revealed marked improvement in cells of acini as well as cells of ducts lining and the acini relatively preserved their shape with strong cytoplasmic

\footnotetext{
* Lecturer of Oral Biology, Faculty of Oral and Dental Medicine, Russian University in Egypt

** Lecturer of Oral Biology, Faculty of Dentistry, Mansoura University, Mansoura, Egypt.

*** Lecturer of Oral Pathology, Faculty of Dentistry, Ain Shams University
} 
immunoreaction of $\mathrm{Bcl}-2$. The immunohistochemical results confirmed the previous results as the highest mean value of Bcl-2 expression was observed in group III, followed by the control group which showed the second highest Bcl-2 mean value. While, the lowest mean value was observed in group II. The difference among the examined groups was statistically significant where the p-value was $<0.001$.

Conclusion: The application of the MSCs could preserve salivary glands from apoptosis by the enhancement of the antiapoptotic activity and it could be used as a new strategy to decrease the harmful effects of methotrexate on submandibular gland tissue.

KEY WORDS: submandibular salivary gland, methotrexate, Bone marrow stem cells.

\section{INTRODUCTION}

Salivary glands are exocrine glands that produce saliva which plays a vital role in maintaining general health of the oral tissues. Saliva has a role in lubrication, digestion, enamel preservation, antibacterial, antifungal and anti-inflammatory functions. The submandibular salivary gland is the second largest salivary gland, it produces about $60 \%$ of saliva ${ }^{(1)}$.

Chemotherapy has been widely used for treatment of cancer. It has cytotoxic effect not only for cancer cells, but also affects the normal tissues, the severity of the damage effect is based on the type, amount and duration of the drug used ${ }^{(2,3)}$. Patients treated with these cytotoxic drugs complain from xerostomia that results in difficulties in swallowing, speech, taste sensation, oropharyngeal pain and oral infections. Hence, cytotoxic drugs produce a structural changes in salivary glands that results in disturbances in their function ${ }^{(4)}$. Drugs used for xerostomia treatment have many side effects such as excessive sweating, tremors, nervousness and diarrhea associated with drugs used for salivary gland stimulation in xerostomia ${ }^{(5)}$. So, it is necessary to find another effective treatment for xerostomia.

Methotrexate (MTX) is one of the important anticancer drugs which is a folic acid antagonist that eliminates the essential antimetabolites involved in DNA synthesis results in cell death ${ }^{(6)}$ and indicated in treatment of rheumatoid arthritis cases with less toxicity and greater tolerability than others ${ }^{(7)}$. Also, it has been used as a therapy to reduce obesity-related inflammation of adipose tissue ${ }^{(8)}$. MTX causes the acute injury on the submandibular salivary gland as it induces apoptosis after treatment. Thus, the relation between cell proliferation, differentiation, and apoptosis is a substantial feature in maintaining the normal architecture and function of the submandibular gland ${ }^{(9)}$.

Apoptosis is considered a programmed cell death which plays a major part in homeostasis and cell growth. Homeostasis is responsible for the regulation of salivary gland tissue when affected by several stimuli. One of the critical genes involved in apoptotic pathway is the Bcl-2 that acts as an oncogene which inhibits the cell death rather than activation of cell proliferation ${ }^{(\mathbf{1 0}, 11)}$.

Furthermore, apoptosis is regulated by proteins of the Bcl-2 family that acts at the mitochondrial level. This protein family can be divided into three groups according to the different function and structure. First, the BH-3 proteins that respond to apoptotic stimuli and activate the proapoptotic proteins Bax and Bak which activate the caspases protein cascade and finally the antiapoptotic proteins like Bcl-2 that suppress the action of pro-apoptotic proteins ${ }^{(\mathbf{1 2}, \mathbf{1 3})}$.

Many therapeutic strategies have been done to recover or regenerate the damaged salivary glands including gene therapy, construction of tissue-engineered artificial gland, re-implantation of autologous salivary gland cells and stem cell 
therapy ${ }^{(\mathbf{1 4})}$. Mesenchymal stem cells (MSCs) are multipotent stem cells that can be differentiated into many cell types, including chondrocytes, adipocytes, osteoblasts, acinar cells, and salivary epithelial cells. They were used in regenerative medicine and have the ability to repair the damaged tissues with anti-inflammatory effects and low immunogenicity. Therefore, MSCs were investigated for regeneration and functional restoration of the damaged salivary gland ${ }^{(15)}$.

MSCs derived from bone marrow are observed to migrate to the damaged salivary glands after intra glandular and intravenous injections in rats. Bone marrow stem cells (BMSCs) has the ability to increase the proliferation capacity of injured cells in different tissues ${ }^{(16,17)}$.

Few studies have been performed to investigate the effect of MSCs on destructed salivary gland tissues. Therefore, the purpose of this study was conducted to evaluate the effect of local injection of bone marrow stem cells on submandibular glands of rats receiving Methotrexate as chemotherapeutic drug histologically and immunohistochemically.

\section{MATERIAL AND METHODS}

Thirty male adult pathogen-free albino rats, weighing 150-200 gm were selected for this study. They were housed in Medical Experimental Research Center (MERC) in Faculty of Medicine, Mansoura University. Rats received water ad libitum and a standard pelleted diet and were kept in a $12 \mathrm{~h}$ light/dark cycle. All experimental procedures were performed under protocol of ethical committee of Faculty of Dentistry, Mansoura University, Egypt.

\section{Study design}

The rats were randomly divided into three equal groups; ten for each.

Group I (negative control): rats received $1 \mathrm{ml}$ Phosphate buffered saline (PBS) once daily and kept in the housing conditions as the test groups.

Group II (positive control): rats received single intraperitoneal injection of $40 \mathrm{mg} / \mathrm{kg}$ Methotrexate (MTX) freshly dissolved in $1 \mathrm{ml}$ PBS at day one of the experiment ${ }^{(4)}$.

Groups III (stem cell treated): rats were handled as those in group II; however, rats were subjected to intra glandular injection of Bone marrow mesenchymal stem cells BMMSCs ( 1 x $10^{(6)}$ cells) suspended in $0.1 \mathrm{ml}$ PBS 7 days after the start of the experiment ${ }^{(18)}$. Animals of all groups were euthanized three weeks after the start of experiment. All surgical steps were performed in the Surgical Unit of MERC, Mansoura University, Egypt.

\section{Isolation and culture of BMMSCs}

All in vitro steps were performed in the Stem cell Unit of MERC, Mansoura University, Egypt. BMSCs were isolated as follows. Briefly, Healthy 3-4 weeks white albino rats were euthanized with overdose chloroform anesthesia and cervical dislocation according to the guidelines laid down by the National Institute of Health (NIH) in the USA. Both, femora and tibia were aseptically removed. Bone heads at the ends of the diaphysis were cut from the femur and tibia, then a disposable aseptic syringe was used to flush out bone marrow using modified eagles' culture medium ( $\alpha$-MEM), supplemented with $10 \%$ fetal bovine serum (FBS), $50 \mathrm{IU} \mathrm{L}^{-1}$ penicillin, freshly prepared ascorbic acid (AA) $(50 \mu \mathrm{g} / \mathrm{ml}), 2 \mathrm{~mL}$-glutamine, $0.3 \mu \mathrm{g} \mathrm{mL}-1$ fungizone, $50 \mu \mathrm{g} \mathrm{mL}-1$ streptomycin, $50 \mu \mathrm{g} \mathrm{mL}^{-1}$ gentamycin sulphate, $10^{-8} \mathrm{M}$ dexamethasone, 10 $\mathrm{mM} \beta$ glycerophosphate $(\beta-\mathrm{GP})$. Cells were allowed to adhere for 5-6 days, then the non-adherent cell population was discarded and the culture medium was replaced with fresh culture $\alpha$-MEM medium twice a week. Confluence was reached $80 \%$ on days14-21 of cell cultures, after which the cells were trypsinized and subcultured ${ }^{\left({ }^{(19)}\right.}$. 


\section{Characterization}

The flowcytometric immunophenotype was determined using a BD Accuri C6 flow cytometer and program software. Digested passage 3 (P3) BMSCs that reached an optimal growth state were rinsed in PBS, then resuspended in $0.5 \mathrm{~mL}$ PBS. Rabbit polyclonal anti-CD45 antibody, Anti-CD44 antibody and Mouse monoclonal Anti-CD105 antibody (Abcam, Cambridge, United Kingdom) were added separately, then incubated for $30 \mathrm{~min}$ in the dark at $4{ }^{\circ} \mathrm{C}$. Labeled BMSCs were rinsed in PBS, then centrifuged at $200 \times g$ for $5 \mathrm{~min}$ and resuspended in PBS.

\section{Preparation of BMMSCs for injection}

When the cell confluence reached the required number, plastic syringes of $100 \mathrm{IU}$ were loaded with stem cell suspension. Each syringe containing 0.1 $\mathrm{ml}$ of PBS carrying $1 \times 10^{6}$ BMMSCs ${ }^{(20)}$.

\section{Intragalndular injection}

The animals of group III were anethetized via intra peritoneal injection of $50 \mathrm{mg} / \mathrm{kg}$ sodium pentobarbitol, and subsequently BMMSCs were injected through the capsule of both submandibular salivary glands of each animal ${ }^{(21)}$.

\section{Histological evaluation:}

The animals of each group were euthanized by overdose of diethyl ether, then pairs of SMG were dissected out and fixed in 10\% neutral buffered formaline after that, submandibular salivary gland of each rat were processed for paraffin blocks in Pathology department, Faculty of Medicine, Mansoura University and prepared for histological examination by Haematoxylin and Eosin (H\&E) stain as routine stain.

\section{Immunohistochemical staining:}

In summary, immunohistochemical staining was performed using the peroxidase-antiperoxidase method as follows: as follows: the sections were deparaffinized in xylene, hydrated and washed with tap water. According to the manufacturer's instructions, antigen retrieval was performed. The slides were washed and incubated with Bcl-2 (Lab Vision, USA) antibody overnight at room temperature. The slides were then washed with phosphate buffer saline and incubated with biotinylated antibody for 30 minutes and then washed with phosphate buffer. At the end the peroxidase labeled streptavidin was applied then DAB chromogen was added for antibody staining brown. The samples were then allowed to react with haematoxylin stain then dehaydrated and mounted.

\section{Morphomtrical analysis}

For each positive section, four microscopic fields showing the highest immunopositivity were selected and photomicrographs were taken at a magnification $\mathrm{x} 40$ by a digital camera (CS060. Olympus, Japan). All the steps for image analysis were carried out using image analysis software (Image J. 1.41a, NIH, USA). The area fraction of the positive cells was calculated automatically. The collected data was tabulated in an excel sheet and statistically analyzed using SPSS.

\section{Statistical analysis}

Data was analyzed using Statistical Package for Social Science software computer program version 23 (SPSS, Inc., Chicago, IL, USA). Quantitative data was presented in mean and standard deviation. One way analysis of variance (ANOVA) and tukey were used for comparing quantitative means of the three groups. $P$ value less than 0.05 was considered statistically significant.

\section{RESULTS}

\section{Haematoxylin and Eosin results}

\section{Group I (negative control):}

Examination of (SMG) of this group showed the normal histological structure of the gland. Thin connective tissue C.T septa divided the gland into lobes and lobules. Each lobule contained closely packed serous acini as well as intralobular ducts (intercalated, striated) and granular convoluted tubules that 
were observed between the acini. The serous secretory cells have darkly stained cytoplasm and rounded basophilic nuclei. The intercalated ducts were lined by simple cuboidal epithelium, whereas the striated ducts were lined by columnar cells having oval nuclei. The well-developed granular convoluted ducts were lined by high-columnar epithelial cells having acidophilic cytoplasm (fig.1 a, b).

\section{Group II (positive control):}

Examination of (SMG) of this group showed glandular disorganization. The secretory acini showed ill-defined outlines and multiple intracytoplasmic vacuoles. Wide connective tissue septa enclosed dilated congested blood vessels, mononuclear infiltration and eosinophilic material condensation was observed between the acini. The acinar and ductal cells showed shrunken darkly stained nuclei and they were compressed by their cytoplasmic vacuoles. While, some acini were shrunken leaving spaces filled with infiltrating mononuclear cells. The nuclei of the acinar cells revealed different sizes and shape (polymorphism). Moreover, the intralobular ducts could not be easily differentiated into striated and intercalated. The cells of the striated ducts showed cytoplasmic vacuoles with disturbed basal cell membrane. Some granular convoluted tubules ducts showed destruction of their epithelial cell lining. Some interlobular excretory ducts were dilated with cytoplasmic vacuolation of their lining epithelial cells, while others showed destruction of their lining epithelium (fig.1 c, d, e).

\section{Groups III (stem cell treated):}

Examination of (SMG) of this group revealed marked improvement in cells of acini as well as cells of ducts lining and the acini relatively
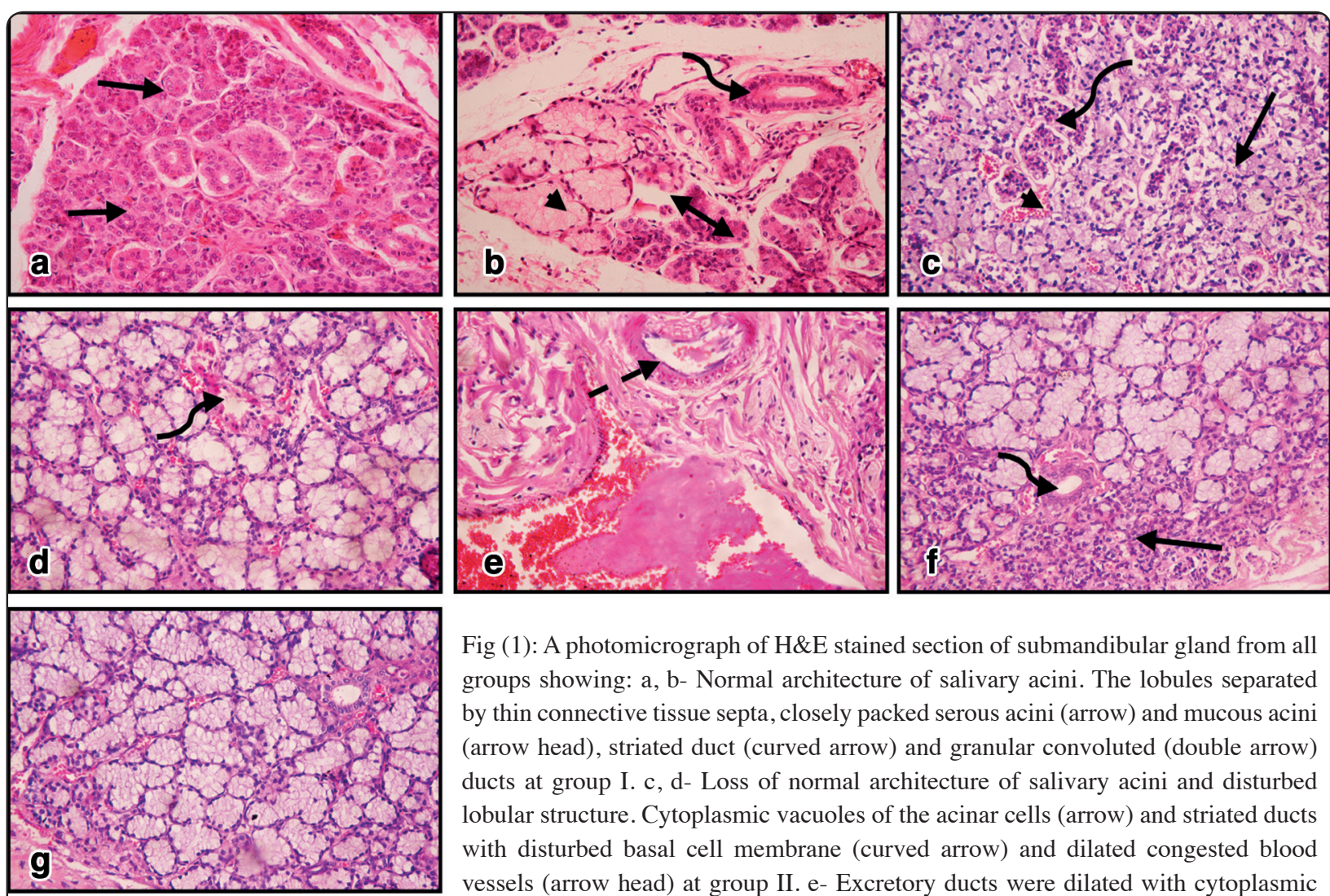

Fig (1): A photomicrograph of H\&E stained section of submandibular gland from all groups showing: a, b- Normal architecture of salivary acini. The lobules separated by thin connective tissue septa, closely packed serous acini (arrow) and mucous acini (arrow head), striated duct (curved arrow) and granular convoluted (double arrow) ducts at group I. c, d- Loss of normal architecture of salivary acini and disturbed lobular structure. Cytoplasmic vacuoles of the acinar cells (arrow) and striated ducts with disturbed basal cell membrane (curved arrow) and dilated congested blood vessels (arrow head) at group II. e- Excretory ducts were dilated with cytoplasmic vacuolation of their lining epithelial cells (dash arrow) at group II. f, g- Relatively normal histology and architecture of salivary ducts and acini. The acini relatively preserved their shape (arrow), decrease in the numbers of cytoplasmic vacuoles, wellformed striated ducts (curved arrow), and few congested blood vessels (original power x40 ). 
preserved their shape, decrease in the numbers of cytoplasmic vacuoles. Well-formed striated ducts with intact epithelial lining were also detected with restored their basal striations. The intercalated ducts were present in between the acini. The granular convoluted tubules were lined by simple columnar epithelium with eosinophilic cytoplasm and basal rounded nuclei. Also, presence of few vacuolations, pyknotic nuclei, congested blood vessels in addition to multiple adjacent acinar lumina (fig. $1 \mathrm{f}, \mathrm{g}$ ).

\section{Immunohistochemical results:}

The immunohistochemical stained sections of the submandibular salivary gland from the Group I (negative control) showed a mild positive immunoreaction of Bcl-2, which appeared as a clear brown color in the cytoplasm of acinar and ductal cells. (fig. $2 \mathrm{a}, \mathrm{b}$ )

Group II (positive control) showed a negative immunoreactivity for Bcl-2 antibody in both ductal and acinar cells. (fig. 2 c, d)

Concerning the immunohistochemical reaction from group III (stem cell treated), there was a strong cytoplasmic immunoreaction of Bcl-2 in most of ductal and acinar cells. (fig. 2 e, f)

\section{Statistical results:}

The mean and standard deviation of the three groups are listed in table (1)

The highest mean value of $\mathrm{Bcl}-2$ expression was observed at group III (38.84), followed by group I which showed the second highest $\mathrm{Bcl}-2$ mean value (18.62).

While, the lowest mean value was observed at group II (0) where it showed a negative immunoreaction. The difference among the examined groups was statistically significant where the p-value was $<0.001$ (Fig. 3, table 1).
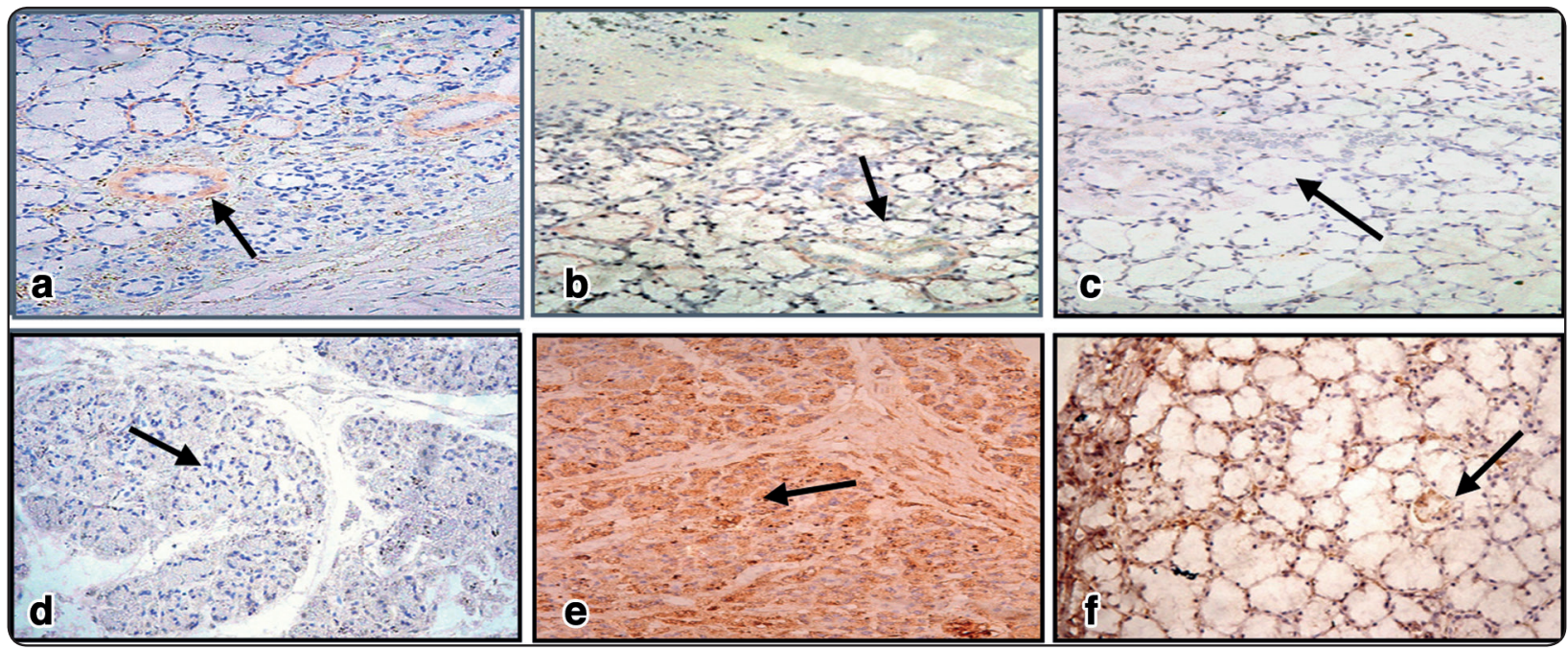

Fig (2): Photomicrographs of rat submandibular gland of Bcl-2 immuno stain from all groups showing: a, b- Mild brown positive immunoreactivity of Bcl-2 (18.62 \pm 1.985$)$ at group I mainly in nuclei of ductal cells (black arrow) and acinar cells. c, d- Negative cytoplasmic immuoreactivity of Bcl-2 (0) at group II in both acinar and ductal cells (black arrow). e, f- Strong cytoplasmic immunoreactivity of Bcl-2 (38.84 \pm 3.904$)$ at group III in both acinar and ductal cells (black arrow) (original power $\mathrm{x} 40$ ). 
TABLE (1) Showed mean \pm SD of the Bcl-2 expression of all groups.

\begin{tabular}{|c|c|c|c|}
\hline & Group I & Group II & Group III \\
\hline BCL2 & $18.62 \pm 1.985$ & 0 & $38.84 \pm 3.904$ \\
\hline Posthoc & & $\mathrm{P} 1=<0.001^{*}$ & $\begin{array}{l}\mathrm{P} 1=<0.001^{*} \\
\mathrm{P} 2=<0.001^{*}\end{array}$ \\
\hline $\begin{array}{l}\text { Data expressed either as mean } \pm \text { SD } \\
\text { Test used: One way ANOVA followed by post-hoc tukey }\end{array}$ \\
$\begin{array}{l}\text { P1: significance relative to Group I } \\
\text { P2: significance relative to Group II }\end{array} \quad$ *:significance $<0.05$ \\
\hline
\end{tabular}

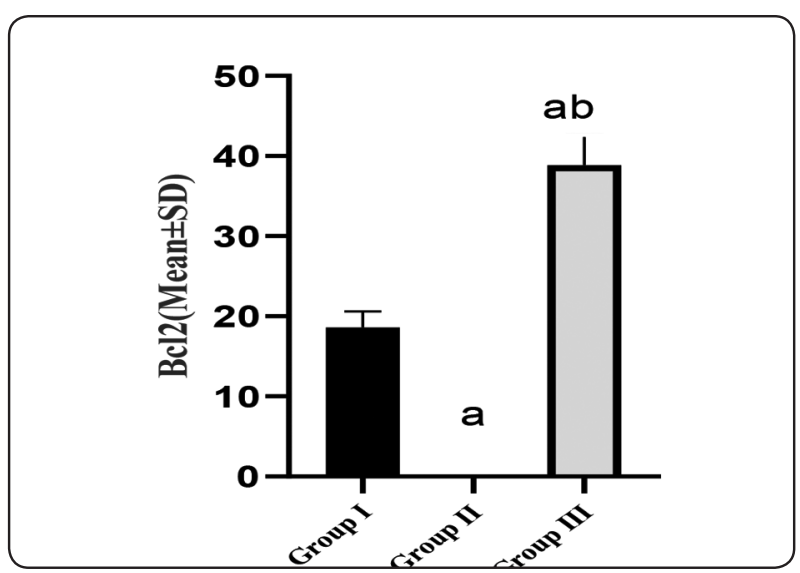

Fig. (3) Bar chart of (Bcl-2) expression for different group.

\section{DISCUSSION}

Submandibular salivary glands secrete a large amount of saliva which has an essential role in maintaining oral tissues healthy. Thus, salivary dysfunction as a result of chemotherapy could lead to oral mucositis that affecting the patient's nutrition along the treatment (22). Decrease in salivary secretion causes dry mouth and a series of complications, including secondary rampant caries, difficulty in chewing and swallowing, loss of taste sensation and oral mucous inflammation, which may affect the quality of life adversely ${ }^{(23) .}$

High dose of Methotrexate causes the acute injury of the submandibular salivary gland as it induces apoptosis after treatment in cancer patients as stated by Bralic, et al., $2005^{\text {(24). }}$ Many authors reported that both folate and folinic acid (leucovorin) reduce the toxicity induced by methotrexate, but Harten, 2005 mentioned that folic acid supplements could reduce methotrexate efficacy in the treatment of cancer ${ }^{(25)}$.

The intraglandular transplantation of bone marrow mesenchymal stem cells increase the salivary production, reduces apoptosis, and increases micro vessel density in irradiated mice as explained by Tran, et al., $2013^{\text {(26). }}$ However, stem cells (SCs) has the ability not only to divide themselves rapidly and continuously, but also to create new SCs and progenitors more differentiated than the mother cells as mentioned by Zhong, $\mathbf{2 0 0 8}^{\text {(27). }}$

This study was conducted to evaluate the effect of local injection of bone marrow stem cells on submandibular glands of rats receiving the chemotherapeutic drug methotrexate histologically and immunohistochemically.

Submandibular salivary gland was the gland of choice at the present study since it produces about $60 \%$ of saliva. Furthermore, the time for a drug required to reach the maximum concentration in submandibular saliva is shorter than that in parotid saliva as reported by Ibrahim, et al., $2004{ }^{(28)}$.

At the current study, light microscopical examination of group I showed granular convoluted tubules that is characterized by their columnar cells containing excretory granules. This finding was agreed with the observation of Miclaus, et al., 
$2009^{(29)}$ who reported that the acini of submandibular glands of rats had the feature of serous acini, similar but not identical with those from parotid gland.

The histological results of our study revealed varying changes in the glandular architecture of submandibular gland at group II including secretory acini with ill-defined outlines and multiple intracytoplasmic vacuoles. Wide connective tissue septa enclosed dilated congested blood vessels and mononuclear cell infiltration. This findings were in agreement with Al-Refai, et al., $2014{ }^{(4)}$ who examined the preventive and earlystage of anticytotoxic effects of green tea on rat's submandibular gland treated by high single dose of methotrexate. Also, in accordance with AlMoula, et al., $2012{ }^{(3)}$ who explained this glandular changes due to suppression of protein synthesis through depletion of foliate co-factors that leads to formation of cytolysosome and apoptotic bodies which are found in small numbers in normal tissues but more increased in tissues that are subjected to cytotoxic agents.

Concerning the damaged salivary gland (acinar and ductal cell vacuolization, apoptosis in the acinar cells with pyknosis in the nuclei) detected at group II. These findings were somehow relevant to Hus, et al., $2006^{(30)}$ who explained these damage effect to the free radicals that released during the intracellular metabolism of methotrexate which act on the cell membrane, causing membrane lysis and release of glutathione based enzymes such as (glucose 6-phosphate dehydrogenase and glutathione reductase) into the serum. Hence, affecting the physiological level of this antioxidant enzyme in serum and induce the adverse effects of this drug on the cellular integrity.

Also, our histological results showed that some ducts dilated with retaining secretion in their lumen, this dilation of ducts suggested the pathological effect of MTX on myoepithelial cells embracing them with failure of expelling the secretion into the oral cavity as a result of glandular dysfunction leading to xerostomia. This comes in agreement with the result of Mahmoud, et al., $2012{ }^{(31)}$ in which the rabbits were injected $(15 \mathrm{mg} / \mathrm{kg}$, i.p.) MTX for two weeks. Additionally, striated ducts could not be distinguished clearly at group II that was detected by epithelial height reduction and loss of basal infoldings. These findings were reported by Al-Refai, et al., $2014{ }^{(4)}$ who explained that MTXinduced degeneration of these duct cells.

The degenerative changes of the acinar and ductal cells were variable. Some acini were swollen with multiple cytoplasmic vacuoles and compressed by this vacuoles. While, some acini were shrunken leaving spaces filled with infiltrating mononuclear cells. This was agreed with Mubarak, $2012{ }^{(32)}$ who explaind these swellings as a result of fatty degeneration and accumulation of lipid droplets within the cytoplasm. These fat droplets might coalesce together forming a large vacuole and consequently lipid degeneration and cellular death in agreement with El-Agamy, et al., $2014{ }^{(33)}$. Lombaert, et al., $2008{ }^{(34)}$ reported that these vacuoles might be due to mitochondrial swelling presence in acini and ducts.

In concern with the marked dilatation and congestion of the blood vessels, mononuclear infiltration was observed between the acini at group II. This findings were in consistent with other studies which explained these inflammatory reactions as a results of mast cells presence within the thickened septa due to transport more blood to the degenerated tissues ${ }^{(35,36)}$

Regarding the dilatation of the striated and excretory ducts with retaining secretion in their lumen which were the obvious findings at group II. These observation might occur as the result of glandular dysfunction and failure of exocytosis. These histological changes were in agreement with Jensen, et al., $2003^{{ }^{(22)}}$ in the statement of use of methotrexate for long term produced salivary gland dysfunction manifested as xerostomia. 
Histological results of group III, revealed marked improvement in cells of acini as well as cells of ducts lining and the acini relatively preserved their shape and showed decrease in the numbers of cytoplasmic vacuoles. These findings were in agreement with studies done by Lim, et al., $2013^{(15)}$ who examined the effect of local BMMSCs transplantation into the submandibular glands of irradiated mice and showed preserved acinar cells and gland morphologies with improved salivary gland secretion. Also, in agreement with Tran, et al., $2013^{(26)}$ who injected BMMSCs in tail veins of mice and rats with irradiated submandibular glands respectively and revealed improvement in submandibular gland functions, increased proliferation, decreased apoptosis and increased vascularity as well.

The salivary gland tissues after local injection by BMSCs showed more regular secretory acini if compared to methotrexate group. A findings were in accordance with Huang, et al., $2015^{(37)}$ who reported that local transplantation of BMMSCs has better results than systemic administration in oral mucosal ulcers and bone defect injuries.

The regeneration of the salivary parenchymal tissues depends on proliferation of cells of the secretory acini, intercalated duct and myoepithelial cells. Under chronic pathological conditions, active proliferation of myoepithelial cells occurs and the proliferation activity elevated two folds in the acinar cells, four folds in intercalated duct lining cells and ten folds in the myoepithelial cells as mentioned by Kujan, et al., $2012{ }^{(38)}$.

Mesenchymal stem cells play a remarkable role in the restoration of deteriorated tissue. It has been clarified that MSCs has a several mechanisms through which it activates tissue regeneration such as production of growth factors and chemokines to stimulate cell growth and angiogenesis, stimulation of anti-inflammatory pathways and finally the antiapoptotic mechanism of MSCs to save the damaged tissue and prevent further cell death ${ }^{(39)}$. So that, the application of stem cell increases the acinar cell proliferation and inhibit cell apoptosis, as well as the differentiation into salivary epithelial cells.

Concerning the immunohistochemical results, the submandibular gland immunostained sections of group I revealed a positive $\mathrm{Bcl}-2$ immunoreaction that was manifested as brown cytoplasmic coloration in the ductal cells and some of the acinar cells with a mean value (18.62 \pm 1.985$)$. While, group II revealed a negative immunoreaction for Bcl-2 in both ductal and acinar cells. These findings were in accordance with Al-Refai, et al, $2014^{(4)}$.

It has been demonstrated that the antiapoptotic Bcl-2 protein helps in the survival of stem cells. In normal salivary gland tissue $\mathrm{Bcl}-2$ is mainly expressed in basal cells of striated and excretory ducts which may refer that these cells are reserve cells in nature, which have the ability to substitute both acinar and duct cells when needed as reported by Horvat, $1995{ }^{(40)}$.

As mentioned before, MTX has a severe side effects on salivary tissues. This fact is consistent with the current study results where the negative immunoreaction of $\mathrm{Bcl}-2$ in group II indicates stimulation of apoptotic pathway in salivary gland tissue, this could be explained by the fact that methotrexate intake has been linked to the increased accumulation of reactive oxygen species (ROS) which in turn results in more oxidative stresses inside the cell that activates the JNK signlling pathway which promotes apoptosis by increasing the proapoptotic promoting genes (Bax and caspases) while decreasing $\mathrm{Bcl}-2$ production ${ }^{(41)}$.

In the present study the stem cell treated group III showed a statistically significant strong positive immunoreaction of Bcl-2 with mean value $(38.84 \pm 3.904)$ in submandibular gland tissue, this finding was in accordance with Mahmoud,

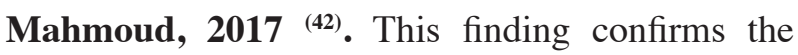
antiapoptotic effect of MSCs where these cells have been observed to increase the antiapoptotic Bcl-2 protein expression and suppress the apoptotic 
caspase- 3 proteins in cardiomyocytes, so protecting them from apoptotic cell death ${ }^{(43) .}$

The various effects of MSCs appeared to occur through a paracrine signalling pathways in the surrounding environment and also through direct cell communication with the formation of intercellular nanotubes with surrounding cells ${ }^{(44) .}$

Concerning the anti-apoptotic properties of MSCs could be due to the paracrine effect of insulin like growth factor 1 (IGF-1) and interleukin - 6 (IL-6 ) secreted by MSCs which activates the PI-3K /Akt and NF- $x \mathrm{~B}$ signalling pathways that mediate the production of antiapoptotic genes such as $\mathrm{Bcl}-2$ and $\mathrm{Bcl}-\mathrm{xL}^{(45,46)}$.

Also, it has been recently hypothesized that MSCs can save the damaged tissue through dual exchange of their mitochondria through the nanotubes. MSCs could save the damaged tissue through the transport of their own healthy mitochondria. However, the role of the mitochondria transferred from damaged cells to MSC remains unknown and need further investigations as mentioned by Mahrouf, $2017^{(47) .}$

\section{CONCLUSION}

The application of the BMMSCs could preserve salivary glands from apoptosis by the enhancement of the antiapoptotic activity and it could be used as a new strategy to decrease the harmful effects of methotrexate on submandibular gland tissue.

\section{RECOMMENDATIONS}

Further investigations are needed to be applied to study the effect of MSCs application on humans.

\section{REFERENCES}

1- Mednieks MI, Szczepanski A, Clark B, Hand AR: Protein expression in salivary glands of rats with streptozotocin Diabetes. Int. Exp. Path. J. 2009; 90: 412-422.

2- Chamani G, Zarei MR, Mehrabani M, Taghiabadi Y: Evaluation of Effects of Zingiber officinale on Salivation in Rats. Acta. Medica. Iranica. J. 2011; 49: 336- 340.
3- Al-Moula AD, Al-Mashhadane F, Mammdoh JK: Effects of 6-mercaptopurine on salivary glands in rabbit. Al-Rafidain Dent. J. 2012; 12: 266-273.

4- Al-Refai AS, Khaleel AK, Ali S: The effect of green tea extract on submandibular salivary gland of methotrexate treated albino rats: immunohistochemical study. Cytol. Histol. J. 2014; 5:212-220.

5- Jellema AP, Slotman BJ, Doornaert P, Leemans CR, Langendijk JA: Impact of radiation-induced xerostomia on quality of life after primary radiotherapy among patients with head and neck cancer. Int. Radiat. Oncol. Biol. Phys. J. 2007; 69: 751-760

6- Klareskog L, Vander Heijde D, de Jager JP, Gough A, Kalden J, et al., :Therapeutic effects of the combination of etanerceept and methotrexate compared with each treatment alone in patients with rheumatoid arthritis: Double blind randomized controlled trial. Lancet. J. 2004; 363: 675-681.

7- Kaltsonoudis, Evripidis, Charalampos Papagoras, Alexandros A. Drosos. "Current and future role of methotrexate in the therapeutic armamentarium for rheumatoid arthritis." Inter. Clinical Rheumatology. J. 2012; 7 (2): 179-89.

8- DeOliveira CC, Acedo SC, Gotardo EM, et al.,: Effects of methotrexate on inflammatory alterations induced by obesity: an in vivo and in vitro study. Molecular and cellular endocrinology. J. 2012; 361:92-98.

9- Bralic M, Muhvic-Urek M, Stemberga V, Golemac M, Jurkovic S, et al.,: Cell death and cell proliferation in mouse submandibular gland during early post-irradiation phase. Acta. Med. Okayama. J. 2005; 59: 153-159.

10- Aljerf L, Alhaffar I: Salivary distinctiveness and modifications in males with diabetes and Behçet's disease. Bio. Res. Inter. J. 2017; 2017:12.

11- Li A, Ojogho O, Escher A: Saving death: Apoptosis for intervention in transplantation and autoimmunity. Clin. Devel. Immunol. J. 2006; 13: 273-282.

12- Youle R, Strasser A: The BCL-2 protein family: opposing activities that mediate cell death. Nat. Rev. Mol. Cell Biol. J. 2008; 9: 47-59.

13- Kutuk O, Letai A: Regulation of Bcl-2 family proteins by post translational modifications. Curr. Mol. Med. J. 2008; 8: 102-118.

14- Arany S, Benoit DS, Dewhurst S, Ovitt CE: Nanoparticlemediated gene silencing confers radioprotection to salivary glands in vivo. Mol. Ther. J. 2013; 21: 1182-1194. 
15- Lim JY, Yi T, Choi JS, Jang YH, Lee S, Kim HJ, Song SU, Kim YM: Intraglandular transplantation of bone marrowderived clonal mesenchymal stem cells for amelioration of post-irradiation salivary gland damage. Oral Oncol. J. 2013; 49: 136-143.

16- Schwarz S, Huss R, Schulz-Siegmund M, Vogel B, Brandau $\mathrm{S}$, et al.,: Bone marrow-derived mesenchymal stem cells migrate to healthy and damaged salivary glands following stem cell infusion. Int. Oral Sci. J. 2014; 6: 154-161.

17- Weil BR, Markel TA, Herrmann JL, Abarbanell AM, Meldrum DR: Mesenchymal stem cells enhance the viability and proliferation of human fetal intestinal epithelial cells following hypoxic injury via paracrine mechanisms. Surgery. J. 2009; 146: 190-197.

18- Zhu P, Chen M, Wang L, Ning Y, Liang J, Zhang H, Xu C, Chen S, Yao L: Systemic mesenchymal stem cells reduce growth rate of cisplatin-resistant ovarian cancer. Int. Clin. Exp. Pathol. J. 2013; 6 (11): 2506-2514.

19- Smajilagić A, Aljičević M, Redžić A, Filipović S, Lagumdžija A: Rat bone marrow stem cells isolation and culture as a bone formative experimental system. Bosn. Basic Med. Sci. J. 2013; 13(1):27-30.

20- Cooney DS, Wimmers EG, Ibrahim Z, Grahammer J, Christensen JM, Brat GA, Wu LW, Sarhane KA, Lopez J, Wallner C, Furtmüller GJ, Yuan N, Pang J, Sarkar K, Lee WP, Brandacher G: Mesenchymal Stem Cells Enhance Nerve Regeneration in a Rat Sciatic Nerve Repair and Hindlimb Transplant Model. Sci. Rep. J. 2016; 6:31306.

21- Zhifa W, Hongyan X, Hanqing, Taiqiang D, Yan W, Zhijin L, Ran A, Haiyan X, Yanpu L, Bin L: Intraglandular transplantation of adipose-derived stem cells combined with platelet-rich fibrin extract for the treatment of irradiation-induced salivary gland damage. Experimental and therapeutic medicine. J. 2018; 15: 795-805.

22- Jensen SB, Pedersen AM, Reibel J, Nauntofte B: Xerostomia and hypofunction of salivary glands in cancer therapy. Support Care Cancer. J. 2003; 11: 207- 225.

23- Vissink A, Burlage FR, Spijkervet FK, Jansma J and Coppes RP: Prevention and treatment of the consequences of head and neck radiotherapy. Crit. Rev. Oral Biol. Med. J. 2003; 14: 213-225.

24- Bralic M, Muhvic-Urek M, Stemberga V, Golemac M, Jurkovic S, et al.,: Cell death and cell proliferation in mouse submandibular gland during early post-irradiation phase. Acta. Med. Okayama. J. 2005; 59: 153-159.
25- Harten P: Reducing toxicity of methotrexate with folic acid. Rheumatol. J. 2005; 64: 353-358.

26- Tran SD, Liu Y, Xia D, et al.,: Paracrine effects of bone marrow soup restore organ function, regeneration and repair in salivary glands damaged by irradiation. PLOS ONE. J. 2013; 8: 616-632.

27- Zhong W. Timing cell-fate determination during asymmetric cell divisions. Curr. Opin. Neurobiol. J. 2008; 18(5):472-478.

28- Ibrahim SH, Soliman ME, Yehia NM: Effect of ciprofloxacin on the submandibular salivary gland of adult male albino rat: A light and electron microscopic study. Egypt. J. Histol. 2004; 27 (2): 339 -354.

29- Miclaus V, Oana L, Ober C, Rus V, Pestean C: Observations concerning features of submandibular gland secretion in rats. Lucrari. Stiinlifice Medicine Veterinara. J. 2009; 9: 382-386.

30- Hus PC, Hour TC, Liao YF, Hun YC, Chang WH, et al.,: Increasing ornithine decarboxylase activity is another way of prolactin preventing methotrexate induced apoptosis: Crosstalk between ODC and Bcl-2. Apoptosis. J. 2006; 11: 389-399.

31- Mahmoud EF, Mahmoud MF, Abd Al Haleem MA: Royal jelly ameliorates oxidative stress and tissue injury in submandibular salivary gland of methotrexate treated rabbits: Immunohistochemical study. American. Science. J. 2012; 8: 501-508.

32- Mubarak R: Effect of Red Bull energy drink on Rats' Submandibular salivary glands (Light and Electron microscopic Study). American Science. J. 2012; 8(1): 366-372.

33- El-Agamy AA, Afifi OK, Sheta AA: Protective Role of Panax Gensing on Fluvoxamine Maleate Induced Structural Changes in the Submandibular Salivary Gland of Rats. Nat. Sci. J. 2014; 12: 21-29.

34- Lombaert IM, Brunsting JF, Wierenga PK, Kampinga HH, de Haan G, Coppes RP: Cytokine treatment improves parenchymal and vascular damage of salivary glands after irradiation. Clin. Cancer Res. J. 2008; 14:7741-7750.

35- Moubarak R: The effect of hypercholesterolemia on the rat parotid salivary gland (histopathological and immunohistochemical study). Cairo Dental J. 2008; 24:19-28.

36- Al-Lami MQ, Sail AS, Al-Chalabi SM, Al-Mahdawi FA: Study the Effects of Methotrexate with and without Vitamin A on Some Biochemical and Histological Parameters in Male Rabbits. Biotechnology Research Center. J. 2017; 11(1): 45-53. 
37- Huang S, Xu L, Zhang Y, Sun Y, Li G: Systemic and Local Administration of Allogeneic Bone Marrow-Derived Mesenchymal Stem Cells Promotes Fracture Healing in Rats. Cell Transplant. J. 2015; 24(12): 2643-55.

38- Kujan O, Othman R, Alshehri M, Iqbal F, Kochaji N: Proliferative Activity of Myoepithelial Cells in Irradiated Rabbit Parotid and Submandibular Salivary Glands. Int. Oral Health. J. 2015; 7(2):1-5.

39- Murphy M, Moncivais K, Caplan A: Mesenchymal stem cells: environmentally responsive therapeutics for regenerative medicine. Exper. Mol Med. J. 2013; 45:54.

40- Horvat R, Weninger W, Ulrich W: Expression of bcl-2 in Salivary Glands and Salivary Gland Adenomas: a contribution to the reserve cell theory. Pathol. Res. Prac. J. 1995; 191: 35-41.

41- Vardi N, Parlakpinar H, Ates B, Cetin A, Otlu A: Antiapoptotic and antioxidant effects of beta-carotene against methotrexate-induced testicular injury. Fertil. Steril. J. 2009; 92: 2028-2033.

42- Mahmoud E, Mahmoud M: Effect of pomegranate peel extract on submandibular salivary glands of streptozotocin induced diabetes in rats: histological, immunohistochemical and ultrastructural study. Adva. Biol. Biotech. J. 2017; 13: 1-15.

43- He A, Jiang Y, Gui C, Sun Y, Li J, Wang J: Antiapoptotic ef- fect of mesenchymal stem cell transplantation on ischemic myocardium is enhanced by anoxic preconditioning. Can. Cardiol. J. 2009; 25:353-358.

44- Liu K, Ji K, Guo L, Wu W, Lu H, Shan P, Yan C: Mesenchymal stem cells rescue injured endothelial cells in an in vitro ischemia-reperfusion model via tunnelling nanotube like structure-mediated mitochondrial transfer. Microvasc. Res. J. 2014; 92: 10-18.

45- Mitsiades C, Mitsiades N, Poulaki V, Schlossman R, Akiyama M, Chauhan D, Hideshima T, Treon S, Munshi N, Richardson P, Anderson K: Activation of NF-kappaB and upregulation of intracellular anti-apoptotic proteins via the IGF-1/Akt signaling in human multiple myeloma cells: therapeutic implications. Oncogene. J. 2002; 21: 5673 5683.

46- Konopleva M, Konoplev S, Hu W, Zaritskey A, Afanasiev B, Andreeff M: Stromal cells prevent apoptosis of AML cells by up-regulation of anti-apoptotic proteins. Leukemia. J. 2002; 16: 1713-1724.

47- Mahrouf-Yorgov M, Augeul L, Da Silva C, Jourdan M, Rigolet M, Manin S, Ferrera R, Ovize M, Henry A, Guguin A, Meningaud J, Dubois-Randé J, Motterlini R, Foresti R, Rodriguez A: Mesenchymal stem cells sense mitochondria released from damaged cells as danger signals to activate their rescue properties. Cell death differ. J. 2017; 24: 1224-1238. 